$\mathbf{R}_{\text {ESEARCH }} \mathbf{P}_{\text {APER }} \longrightarrow$ FOOD SCIENCE e ISSN-2230-9403 - Visit us : www.researchjournal.co.in Volume 9 | Issue 1 | April, 2018 | 48-52 DOI : $10.15740 / \mathrm{HAS} / \mathrm{FSRJ} / 9.1 / 48-52$

\title{
Standardisation, nutritional and sensory analysis of jackfruit Halwa
}

\author{
S. Jayashree and D.H. Jayasheela
}

The study aimed to develop Jackfruit Halwa and to evaluate sensory and nutritional parameters. Jackfruit Halwa were prepared with different variations $\left(\mathrm{T}_{1}, \mathrm{~T}_{2}, \mathrm{~T}_{3}\right.$, and $\left.\mathrm{T}_{4}\right)$ in sweetness. Statistical analysis was done to find the significant difference in sensory parameters in different treatments. The results show that there is significant difference $(\mathrm{P}>0.05)$ between different jackfruit Halwa i.e. $\mathrm{T}_{1}, \mathrm{~T}_{2}, \mathrm{~T}_{3}$ and $\mathrm{T}_{4}$ for quality attributes of taste and over all acceptability, because the variation was made in the sweetness of the product. According to nutritional analysis TSS content varied from $52.7 \pm 0.1$ to $65.1 \pm 0.1$. Titratable acidity of the products varied from $0.32 \pm 0.01$ to $0.48 \pm 0.01$. The Ascorbic acid content was 5.18 $\pm 0.01 \mathrm{in}_{1}$ and $8.17 \pm 0.01 \mathrm{in}_{2}$ product. Total sugar content of developed products varied from $20.67 \pm 0.01$ to $22.43 \pm 0.01$. Non reducing sugars $(\%)$ content was highest in $\mathrm{T}_{1}(20.1 \pm 0.19)$ and lowest in $\mathrm{T}_{4}(17.69)$. The results showed that the developed Jackfruit Halwa of different combinations with respect to sweetness is found to be acceptable by consumers with regard to taste and overall acceptability.

Key Words : Jackfruit Halwa, TSS, Sensory evaluation, Nutritional evaluation

How to cite this article : Jayashree, S. and Jayasheela, D.H. (2018). Standardisation, nutritional and sensory analysis of jackfruit Halwa. Food Sci. Res. J., 9(1): 48-52, DOI : 10.15740/HAS/FSRJ/9.1/48-52. 